\title{
Three unpublished Roman and Byzantine Coins from Oxyrhynchus
}

\section{Dr. Mona Gabr Abd el Naby*}

\section{Abstract:}

This article tackles studying and publishing three coins for the first time; two Roman and a single Byzantine, from the 2015 excavation of the Spanish Expedition in El-Bahnasa (ex. Oxyrhynchus) in Minya Governorate, Middle Egypt.

These three pieces carry the numbers: N.1173, N.1174 and N. 1175, and are preserved now in the Museum journal in ElBahnasa, Hall 8. They could be respectively dated from approximately the $4^{\text {th }}$ century A.D. for the first two coins, unearthed in the site of High Necropolis, and from amidst $7^{\text {th }}$ century A.D., i.e. Late Byzantine till the dawn of the Arab Conquest in $642 \mathrm{AD}$, for the third piece found in the Osirion Site.

The main importance of these coins is not only in spotting light upon some types, and local coinage-industry in Roman and Byzantine Egypt, and their relations to the Alexandrian Mint during that era, but also in clarifying the economic role of Egypt as a Roman Province, and different faces of coinage industry, either produced in Alexandria or being struck in some local mints in other territories throughout Egypt.

\section{Key-words:}

Spanish expedition, Mint, Nomes, coinage, Oxyrhynchus.

\footnotetext{
* Department of Greek \& Roman Archaeology - Cairo University.

- My deep thanks to Prof. Dr. Hassan Amer to give permission, Mr. M. kamal\& Mr. A. Fahmy from the Department of Antiquities in Bahnasa to help by photography, and Ms. NoraMahmoud, assistant, Faculty of Archaeology- Cairo University for giving aid by Facsimile.mona.gabr@hotmail.com
} 


\section{Introduction:}

The Site of Oxyrhynchus ${ }^{(1)}$, mod. El-Bahnasa- Benimazar locality- Minia Governorate, was one of the main nomes, which played an important role in the social and economic activities during the Ptolemaic and Roman eras in Egypt ${ }^{(2)}$.

The several excavations in the site unearthed more evidence thereof, while the coinages' importance lies in the historical story of the region ${ }^{(3)}$. Thus, this article tackles studying and publishing two Roman coins and a single Byzantine one for the first time from the 2015 excavation of the Spanish Expedition, especially the coins found in the Sites of High Necropolis ${ }^{(4)}$ and Osirion ${ }^{(5)}$.

These three pieces carry the numbers: N.1173, N.1174 and N. 1175, and are preserved now in the Museum journal, Hall 8. They could be respectively dated from approximately the $4^{\text {th }}$ century A.D. for the first two coins, unearthed in the site of High Necropolis, and from amidst the $7^{\text {th }}$ century A.D., i.e. Late Byzantine onto the dawn of the Arab Conquest in 642 A.D., for the third piece found in Osirion Site. Here, the three coins will be displayed and presented as follows:

\footnotetext{
${ }^{(1)}$ H. Mac Lennan, Oxyrhnchus, An Economic and Social Study , (Amsterdam, 1968), pp.47-48.; R, Bagnall \& D. Rathbone, Egypt from Alexander to the Copts, An Archaeological and, Historical Guide, (London, 2004), p. 145.

(2) E.G. Turner, "Roman Oxyrhnchus", JEA 38, (London, 1952), pp. 78-93.

${ }^{(3)}$ J. Padro, H. "Excavations in Oxyrhnchus", 120 years of Spanish Archaeology in Egypte,( Cairo, 2009) pp. 322-325.

(4) J. Padro, H. Amer \& M. Erroux -Morfin, "Decouverte et premiers travaux a' l'osireion d' Oxyrhnchus", IX congres international des egyptologues Grenoble 6-12 de Septembre 2004, OLA 50, (leuven, 2007), pp. 1443-1454.

${ }^{(5)}$ H.I. Amer, "Les catacombes osiriennes d'Oxyrhynchos", Le culte d'Osiris au Ier miullenaire av. J-C., decouvertes et travaux recents, Actes de la table ronde internationale tenue a Lyon, Maison de l'orient et de la mediterranee (Universite Lumiere - Lyon)les 8 et 9 Juillet 2005 , Bibliotheque d' etude 152, (Le Caire,2010), pp. 269-282.
} 


\section{Data:}

\begin{tabular}{|c|c|}
\hline \multicolumn{2}{|r|}{ First Piece (pl.1) } \\
\hline Registration & $\begin{array}{l}\text { Bahnasa Journal Serial Nr. 1173- Hall 8, Expedition Register. } \\
\text { Nr. 408- Excavator Nr. OXY 15, } 29064 .\end{array}$ \\
\hline Source & $\begin{array}{l}\text { Spanish Excavations at El-Bahnasa (ex. Oxyrhynchus), } \\
\text { Season 2015, from Site of High Necropolis. }\end{array}$ \\
\hline $\begin{array}{l}\text { Date of Arrival } \\
\text { into Magazine }\end{array}$ & $12 / 4 / 2015$ \\
\hline Material & Lead Token Bronze coin. \\
\hline Weight & Approx. 2.5-2.7 Grams. \\
\hline $\begin{array}{l}\text { size } \\
\text { \&Thickness }\end{array}$ & $2.5 \mathrm{~cm}$. (diameter), $5 \mathrm{ml}$.(thickness). \\
\hline Dating & $\begin{array}{l}\text { Roman Period, end of the } 3^{\text {rd }}-\text { beginning of the } 4^{\text {th }} \text { Centuries } \\
\text { AD. }\end{array}$ \\
\hline Bibliography & Unpublished. \\
\hline Description & $\begin{array}{l}\text { Regular round bronze coin, no obverse bust, its } \\
\text { denominations have been struck in a shallow way. } \\
\text { Upon obverse the Goddess Athena (?) was depicted inside a } \\
\text { shrine, bearing something not clear and looking to the left. } \\
\text { Upon the reverse the winged (Victoria) was shaped, while } \\
\text { bearing some trophy-wreath (?), or victorious sign and } \\
\text { looking to left. }\end{array}$ \\
\hline
\end{tabular}

\begin{tabular}{|l|l|}
\hline \multicolumn{2}{|c|}{ Second Piece (pl.2) } \\
\hline Registration & $\begin{array}{l}\text { Bahnasa Journal Serial Nr. 1174- Hall 8, Expedition Register. } \\
\text { Nr. 409- Excavator Nr. OXY 15, 29066. }\end{array}$ \\
\hline Source & $\begin{array}{l}\text { Spanish Excavations at El-Bahnasa (ex. Oxyrhynchus), } \\
\text { Season 2015, from Site of High Necropolis. }\end{array}$ \\
\hline $\begin{array}{l}\text { Date of Arrival } \\
\text { into Magazine }\end{array}$ & $12 / 4 / 2015$. \\
\hline Material & Lead Token Bronze coin. \\
\hline Weight & Approx. 2.3 - 2.5 Grams. \\
\hline $\begin{array}{l}\text { size } \\
\text { \&Thickness }\end{array}$ & 2 cm.(diameter), 3 ml.(thickness). \\
\hline Dating & $\begin{array}{l}\text { Roman Period, end of the 3 } \\
\text { AD. }\end{array}$ \\
\hline Bibliography & Unpublished. \\
\hline
\end{tabular}




\begin{tabular}{|c|c|}
\hline Description & $\begin{array}{l}\text { Regular round bronze coin, no obverse bust, its } \\
\text { denominations have been struck in a shallow way, but clearer } \\
\text { than the previous one. } \\
\text { Upon obverse an unknown Goddess was depicted, bearing } \\
\text { some sign, she could be Athena, Nike (Victoria), or also } \\
\text { Tyche (Fortuna). Upon reverse a winged Goddess, may be } \\
\text { Nike or Tyche, was shaped, while holding a trophy-wreath } \\
\text { (?), and looking to left. }\end{array}$ \\
\hline \multicolumn{2}{|r|}{ Third Piece (pl.3) } \\
\hline Registration & $\begin{array}{l}\text { Bahnasa Journal Serial Nr. 1175- Hall 8, Expedition Register. } \\
\text { Nr. 410- Excavator Nr. OXY 15, } 29002 .\end{array}$ \\
\hline Source & $\begin{array}{l}\text { Spanish Excavations at El-Bahnasa (ex. Oxyrhynchus), } \\
\text { Season 2015, from Site of Osirion. }\end{array}$ \\
\hline $\begin{array}{l}\text { Date of Arrival } \\
\text { into Magazine }\end{array}$ & $12 / 4 / 2015$ \\
\hline Material & 12 Nummi Bronze coin. \\
\hline Weight & Approx. $2.5-2.7$ Grams. \\
\hline $\begin{array}{l}\text { size } \\
\text { \&Thickness }\end{array}$ & $2.5 \mathrm{~cm}$. (diameter), $5 \mathrm{ml} .($ thickness). \\
\hline Dating & Byzantine Period, Seventh Century AD., about 610- 641 AD. \\
\hline Bibliography & Unpublished. \\
\hline Description & $\begin{array}{l}\text { Oval bronze coin, Type " } 12 \text { Nummi", which belongs to } \\
\text { Alexandrian Mint during the } 5^{\text {th }} \text { to the } 7^{\text {th }} \text { Centuries AD. } \\
\text { Upon obverse a bust-portrait of The Emperor Heraclios, or } \\
\text { the Persian King Khesro II is depicted (?), where he put the } \\
\text { Roman military coat (Paldumentum = Greek Chlamide), } \\
\text { upon his head he has the military helmet adorned with the } \\
\text { "Cross", an unclear denomination for an armor may be also } \\
\text { depicted beside a atar to the left. } \\
\text { Upon the upper half of the reverse the Number } 12 \text { was } \\
\text { inscribed in Greek Letters, relating to the value of the coin, } \\
\text { i.e. } 12 \text { (Nummi), where the Letter (I) means (10), and the } \\
\text { Letter (B) means (2). Both Letters are separated with the } \\
\text { Shape of (Cross). } \\
\text { A horizontal line divides the verso, where upon the lower part } \\
\text { stands a Greek inscription of the four Letters: An } \sum \Xi \text { as an } \\
\text { abbreviation to the name of Alexandria, also in Greek, and } \\
\text { not Latin Letters, as evidence that our piece was struck in an } \\
\text { Alexandrian Mint. }\end{array}$ \\
\hline
\end{tabular}




\section{Study and Analysis:}

Scholars know the difficulties of studying bronze-coinage, which show damaged or flat relieves in general and specifically those among the struck material that were produced in the eastern Mints of the Roman Empire. ${ }^{(6)}$ As for the bronze-coinage of the main Alexandrian mints and other local ones much populated centers in Egypt at that time ${ }^{(7)}$ were often influenced by remarkable Egypto-Greek denominations ${ }^{(8)}$, where beard varied features were practiced, either in depicting definite deities or in preferring Greek script to $\operatorname{Latin}^{(9)}$, along with some other different alterations in size, weight, and dating denominations ${ }^{(10)}$.

The Alexandrian coinages were first produced according to Ptolemaic Style ${ }^{(1)}$ and standard weight, but moving forward towards the Roman Period, they showed decrease in size and weight $^{(12)}$.

(6) R. Carson\& J.Kent, Late Roman Bronze Coinage A D 324-498, (London, 1960), pp. 31-33.

(7) K. Emmett, Alexandrian Coins, (Wisconsin, 2001), p. 13.

(8) D.Klose \& B. Overbeck, Agypten Zur Römerzeit, Antikesleben auf grund der Numismatischen Quellen mit einem ägyptologischen Beitrag von Sylvia Schoske, (München, 1989), p. 60.; E. Christiansen, "Roman Coins of Alexandria", Proceedings of the $20^{\text {th }}$ International Congress of Papyrologists, Copenhagen 23 - 29, August 1992, (ed) A. B. Jacobson, (Copenhagen, 1994), pp. $478-483$.

(9) A.Geissen, "La politique Monëtaire des Antonins", L'exception ëgyptienne?, production et ëchanges monëtaires en Egypte Hellënetique et romaine, Actes du colloque d' Alexandire, 13-15 Avril 2002, Ëtudes älexandrines 10, (Le Caire, 2005), pp. 320-323.; R. Bland, "The roman Coinage of Alexandria, 30 B.C, Archaeological Research in Roman Egypt", The Proceedings of the Seventeenth Classical Colloquium of the Department of Greek and Roman Antiquities, British Museum, 1 - 4 December 1993, (ed) D. Bailey, (Ann Arbor, 1996), pp. 113 - 127.

(10) Emmett, Alexandrian Coins, p. 14.

(11) D. Sear, Greek Imperial Coins and their Values, The Local Coinages of the Roman Empire, (London, 1982), pp. 23 - 29; D. Sear, Greek Imperial Coins and their Values, Vol. II, Asia and North Africa, (London, 1951), pp. 731 - 754.; Ch. Howgego, Ancient History from Coins, (London and New York, 2005), p. 10 .

${ }^{(12)}$ Emmett, Alexandrian Coins, p. 14. 
Despite the fact that many Egyptian coinages outside Alexandria expressed themselves as imitating copies $^{(13)}$, some other local coins reflected extra geographical or divine features ${ }^{(14)}$, when giving concise scripts indicating to the polis where they were struck or the shape of a deity in their zone ${ }^{(15)}$.

The bronze coinages were struck in several nomes of Roman Egypt, Alexandria, for the main metropolis had some known mints. Moreover, many other local mints were present nearby, such as those in Memphis ${ }^{(16)}$, Sais ${ }^{(17)}$, Arsenoie (mod. KimanFaris in Fayyum), Heracleopolis ${ }^{(18)}$ (mod.Ihnasia El-madineh, Antoniopolis (mod. Sheikh Abada), Hermopolis ${ }^{(19)}$ (mod.AlAshmunein), Coptos ${ }^{(20)}$ (mod.Qeft), and Oxyrhynchus (mod.ElBahnasa) ${ }^{(21)}$.

The so called: "Lead tokens had no obverse bust portraits bronze coins"(22) stand among the well-known groups of simultaneous coinage that is classified to considerable difficulties in studying, since they are mainly small and fragile, and they have no or scarce inscriptions or portraits, that could facilitate their exact identification or accurate dating, such as our two pieces presented here; N. 1173 \& N. 1174 (pl.1, 2).

\footnotetext{
(13) Emmett, Alexandrian Coins, p. 15.

(14) R. S. Poole, Catalogue of the Coins of Alexandria and the Nomes, (Bologna, 1964), pp. 28-30.

${ }^{(15)}$ R. S. Poole, Catalogue of the Coins, pp. 28-30.

(16) Emmett, Alexandrian Coins, p. 15.

${ }^{(17)}$ R. S. Poole, Catalogue of the Coins, p 359.

${ }^{(18)}$ R. S. Poole, Catalogue of the Coins, p 356.

${ }^{(19)}$ Klose \& Overbeck, Agypten Zur Romerzit, pp. 50 - 51. N. 155 - 160.; Poole, Catalogue of the Coins, p p. $360-361$.

(20) M. Amandry \& F. Planet, "Corpus des Monnaies de Coptos", Topoi supplement 3, (Lyon, 2002), pp. 166-171.

${ }^{(21)}$ R. S. Poole, Catalogue of the Coins, pp. 45- 46.; Emmett, Alexandrian Coins, p. 15.

${ }^{(22)}$ E. Christiansen, Coinage in Roman Egypt, The hoard Evidence, ( Aarhus, 2004), p. 52.
} 
J. Milne ${ }^{(23)}$ has published 44 pieces out of this abovementioned collection, which came also from previous excavations in Oxyrhynchus, in 1897- 1908, within the "Catalogue of Alexandrian Roman Coins". This collection of coinage was struck for restricted use within its home zone, i.e. Oxyrhynchus itself, dating them from 180- $260 \mathrm{AD}^{(24)}$.

This doctrine is not accepted anymore, because the followed excavations and researches proved several other places, and also different dates for this type of coinage ${ }^{(25)}$.

Later on, K. Emmett ${ }^{(26)}$ gave an exact typology to this collection of coins; dating them to the 1 st until the $3^{\text {rd }}$ centuries AD. The following table shows a comparison in regard to the views of J. Milne and K. Emmet:

\begin{tabular}{|c|l|l|}
\hline \multicolumn{3}{|c|}{ No Obverse Bust Portrait Lead Tokens Bronze Coins } \\
\hline \multicolumn{2}{|c|}{ Not Dated no Inscriptions } \\
\hline Ser. & \multicolumn{1}{|c|}{ Obverse } & \multicolumn{1}{|c|}{ Reverse } \\
\hline 1 & Athena Bust (R.) & Nike Flying (R.) \\
\hline 2 & Athena Advancing (R.) with Nike + Serpent & Nike Flying (L.) \\
\hline 3 & Athena Seated (L.) & $\begin{array}{l}\text { Nike Flying (R.) Nike } \\
\text { Flying (R.) }\end{array}$ \\
\hline 4 & Athena Standing (L.)/ in A Temple with Nike & Nike Flying (L.) \\
\hline 5 & Nike Standing (L.) holds Scepter/ eagle & Eagle Standing (L.) \\
\hline 6 & Nike Standing (L.) & Figure Seated (L.) \\
\hline 7 & Tyche Standing (L.) & Nike Flying (R.) \\
\hline 8 & $\begin{array}{l}\text { Athena Advancing (L.) with Serpent/ Double } \\
\text { Axe }\end{array}$ & Nike Flying (L.) \\
\hline
\end{tabular}

(23) J. Milne, Catalogue of the Alexandrian Coins, (Oxford, 1933)Nos. 5216-5319.

(24) Milne, Catalogue of the Alexandrian Coins, p. 15

(25) Christiansen, Coinage in Roman Egypt, p. 52.

(26) Emmett, Alexandrian Coins, pp. 223- 230, pp. 261 - 263. 


\section{Comparative Study:}

When we compare the types in the above table with our two pieces N. 1173 and N. 1174, we find close similarity between examples 1-8, with some minor differences such as the direction of the head of human shapes, whether the sovereigns or deities. I propose that our coin N. 1173 could well match with type 4 in the table, where- on the observe- the Goddess Athena is depicted within a shrine, holding a symbol or shape of Nike (?), looking to the left, while upon the reverse the winged Nike shows herself looking to the left also, and raising the right arm holding some crown or trophy wreath ${ }^{(27)}$.

As for piece N. 1174, it may be a duplicate of type 8 in the table, where - on the obverse- Athena is holding the double axe and advancing towards the left, while her snake shows itself behind her. On the reverse, Nike is depicted looking to the left and raising the right arm holding some sort of crowns or trophy wreath $^{(28)}$, as the previous piece N.1173.

\section{Type of Coinages of Oxyrhynchus during the Roman Period:}

The local standard type of coinages of Oxyrhynchus ${ }^{(29)}$ displays the Goddess Athena, on obverse, where she stands wearing the Chiton, the Peplos, and the military helmet, holding the double axe in her hand ${ }^{(30)}$. Athena there was assimilated with the local deity of the territory, i.e., Tweres (Egy. Taweret)

(27) Emmett, Alexandrian Coins, N. 4417, p. 224.; J. M. Jones, A Dictionary of Ancient Roman Coins, (London, 1990), pp. 319 - 320.

(28) Emmett, Alexandrian Coins, p. 15.; Jones, A Dictionary of Ancient Roman Coins, p. 320.

${ }^{(29)}$ K. W. Harl, Coinage in the Roman Economy, 300 B.C. -A.D. 700, (London, 1996), p. 209, p. 233.; Poole, Catalogue of the Coins, pp. $360-361$.

${ }^{(30)}$ R. Bagnall, Currency and Inflation in Fourth Century Egypt, (Colombia, 1985), p. 150, N. $132-134,147$, p. 125 , N. 517. 
goddess of motherhood, shaped normally as female hippopotamus. In spite of this close relation, Athena retained her standard form, as depicted normally by the Greek and Alexandrian way ${ }^{(31)}$.

The local coinages of Sais ${ }^{(32)}$ (a famous metropolis in Delta) show also close similarity with that of Oxyrhynchus, where Athena was compacted with the main local deity there, namely: $\mathrm{Neith}^{(33)}$, goddess of war, where Athena also kept her standard form on the coins ${ }^{(34)}$.

The depiction of Athena and Nike upon the reverse of coins of Oxyrhynchus could also be compared with some dated simultaneous coinage from Alexandria and other nomes ${ }^{(35)}$, which have also portraits of these Goddesses upon the reverse.

(31) J. Milne, A History of Egypt under Roman Ruler, ( London, 1924), p. 187.

${ }^{(32)}$ Emmett, Alexandrian Coins, p. 15.

(33) Poole, Catalogue of the Coins, pp. $45-46$.

(34) E. Christiansen, Coins of Alexandria and the Nomes, A supplement to the British museum catalogue, (London, 1991), p. 31, N. 53, pl. 12.

${ }^{(35)}$ Compare:

E. Christiansen, Coins of Alexandria, 2 Vols., (Aarhus, 1988), N. 18, 20, 21, pl. II.; Highly Important Ancient Coins, (London, 1984), pp. 49 - 56.; Christiansen, Coinage in Roman Egypt, (2004), p. 203, pl. I.; Christiansen, Coins of Alexandria and the Nomes, (1991), pl. I, 2, 4, 10, 12, N. 442, 7362, 7319, 1469, 1392, 53, 3531, 3534, 1392, 1469.; F. Feuardent, Numismatique Egypte ancienne II, domination romaine, (Paris, 1970), p. 260, N. 33300, 3255, 3359, pls. 34 - 35., pp. 291 - 292, pl. 35, N. 3492., Emmett, Alexandrian Coins, Nrs. E/540 (12), E/609 (8), e/ 3288, (4)., N. 34, 59, 224.; R. A. Hantvedt \& E. Peterson, Coins from Karanis, The University of Michigan Excavations, 1924 - 1935, (Ann Arbor, 1964),

pp. 155 - 156, pl. VIII, N. 381 - 387.; I. konig, Alexandrinische Munzen, (Trier, 1988), N. 233 - 240, N. 136.; H. Mattingly, Coins of the Roman Empire in the British Museum, vol. 5, (London, 1975), pl. $14-15$. 


\section{Dating:}

As for dating of our pieces N. 1173, N. 1174, they both could be dated to the $4^{\text {th }}$ century A.D. depending on the catalogues of $\mathrm{J}$. Milne and K. Emmet, because they are duplicates of the coinages produced throughout Egypt during the $4^{\text {th }}$ century A.D., definitely between years 320-360 $\mathrm{AD}^{(36)}$. These occurrences match together with the changes that Emperor Diockledianos (284-305 AD) ${ }^{(37)}$ did, when the official mints were restricted to few ones, namely only four mints in Alexandria ${ }^{(38)}$. This action was accompanied by reducing the size and weight of coins to 2.5 Grams, so it was originated, namely the new and small "Follestype" ${ }^{\prime(39)}$ in the $4^{\text {th }}$ century AD, that was the "term" of the Roman bronze coinages, till it was replaced by the other term "Nummi" ${ }^{(40)}$.

The question lies in whether this category of coinages was used as private coins ${ }^{(41)}$ or also monopolized within local ${ }^{(42)}$ exchange; it could be also more possible that these coins were also officially accepted or released by the Roman Government ${ }^{(43)}$.

Our third coin N. 1175 (pl.3) could safely date to the Byzantine Period. It displays a famous type of bronze coinage, that was struck in Alexandria during the time of the $5 \underline{\text { th }}$ to the $7^{\text {th }}$

\footnotetext{
(36) T. F. Brunner, "A small Hoard of Fourth Century Bronze Coins From Egypt", ZPE. 66, (Boon, 1986), p. 285.

(37) Klose \& Overbeck, Ägypten Zur Römerzeit p. 66ph.; Harl, Coinage in the Roman Economy, pp. $116-124$.

(38) Carson \& Kent, Late Roman Bronze Coinage, pp. 42 - 44.

(39) Bagnall Currency, pp.12-13, pp. $19-25$.

(40) Bagnall Currency, p. 37.

(41) Brunner, "A small Hoard", p. 287.

(42) Milne, Catalogue of the Alexandrian Coins, p.17.

${ }^{(43)}$ Christiansen, Coinage in Roman Egypt, (2004), p. 52.
} 
$\mathrm{AD}^{(44)}$. It could also be counted among the "not easy to decipher" coinages, nevertheless its use was not restricted to Alexandria ${ }^{(45)}$, but many pieces thereof were found in many other nomes, with new weight and pronoun" Nummi" ${ }^{(46)}$, that came into market later after the "Folles"(47), and is assumed to be active exclusively throughout Egypt and not within the whole Byzantine Empire ${ }^{(48)}$.

Therefore, our "12 Nummi" coin from Oxyrhynchus matches completely the hundreds of equal pieces, especially during the reigns of the Emperors Gustinian I, Gustinian II,Fucas, Heraclius, and his sons ${ }^{(49)}$, whether these exhibited in the GrecoRoman Museum of Alexandria ${ }^{(50)}$, or those explored by the Italian Expedition in the nearby site, from Oxyrhynchus, Antoniopolis ${ }^{(51)}$, namely Sheikh Abada, in the North Necropolis, during several seasons since 1937-2007.

The denominations of this collection of coinages show frequently bust-portraits, one thereof is bigger than the other, of two personalities, i.e. the Emperor Heraclius with his son and successor Heraclius-New-Costantinos, but when there is only one bust-portrait, like our coin N. 1175, the personality depicted may rather exhibit the unbeard Khesru $\mathrm{II}^{(52)}$, the Persian king, wearing the helmet adorned with the "cross", and a star is also pictured to

(44) S. A. Abbas, "Some Overstruck Coins from the Time of Heraclius", L'exception ëgyptienne?, Etudes älexandrines 10, (Le Caire, 2005), p. 339.

(45) Abbas, "Some Overstruck Coins", p. 339.

(46) Bagnall Currency, pp. 12 - 13.

(47) Carson \& Kent, Late Roman Bronze Coinage, pp. 103 - 105.

(48) Abbas, "Some Overstruck Coins", p. 340, Note. 2.

${ }^{(49)}$ Klose \& Overbeck, Ägypten Zur Römerzeit, pp. 86 - 87., N. 265 - 273.

(50) Abbas, "Some Overstruck Coins", p. 339 - 357.

(51) D. Castrizio, Le monete della Necropoli Nord di Antinoupolis, (1937 - 2007), (Firenze, 2010), pp. $9-10$, p. 29 N. 1, 2, 3, pp. $75-125$, N. $1-309$, pp. $138-151$, N. $70-155$, p. 162 , N. $36-37$, pp. $328-333$, N. $102-134$, pp. $342-350$, N. $74-124$, pp. $353-354$, N. $27-34$.

${ }^{(52)}$ D. Sear, Byzantine Coins and their Values, (London, 1974), p. 163, N. 855. 
the left; this means that these coinages were struck in Alexandria during the Persian invasion during the reign of Heracles, and imitated by some other local mints in some nomes, mainly in Upper and Middle Egypt. Thus, this collection of coinages could be almost dated either to the time of the exchange held between Heraclius and Khesru II, within 618-628 AD, according to the assertion of Sear ${ }^{(53)}$, or rather dated, as the author assumes, along the whole reign era of Heraclous and his sons, from 610$642 \mathrm{AD}^{(54)}$,ending with the Arab Conquest.

\section{Conclusion:}

According to some known scholars, Egypt was a mere Roman province, where the standard currency system of the whole empire was in action, with not only all its indications to Roman traditions, politics, divine events, but also to all its memorials, main visits of different Emperors, besides serving as a register of some of the great victories ${ }^{(55)}$.

Nevertheless, this accurate organized system sometimes accepted some few Egypto-Greek details ${ }^{(56)}$ or features that were adopted as characteristic denominations for the coinage industry, whether struck within the Alexandrian mints or those produced in the other known mints all over Upper and Lower Egypt. Thus, it seems that a "closed currency System" ${ }^{(57)}$ was used throughout Egypt. This system made it easy for some extra facilities to find

(53) Sear, Byzantine Coins, pp. $162-164$.

(54) Abbas, "Some Overstruck Coins", p. 339.

(55) A. Burnett, "The Imperial Coinage of Egypt in the Frist Century A D., L'exception ëgyptienne?, Ëtudes älexandrines 10, (Le Caire, 2005), p. 275.

(56) Christiansen, Coinage in Roman Egypt, (2004), p. 142.

${ }^{(57)}$ M. el-Amouri et O. Picard, "Etudes ëxperimentales et Mëtallurgiques du moulage de monnaies et bronze de la fin de l' empire romain, L'exception ëgyptienne?, Ëtudes älexandrines 10, (Le Caire, 2005), pp. 225 - 252. 
their way to action in this Roman province more than others ${ }^{(58)}$. It is obvious also that despite the commitment of all the local mints, including of course Oxyrhynchus itself, to the imitation of the denominations belonging to the products of the Alexandrian ones, the majority of them kept some peculiarities in size, weight, row materials, and also some few special denominations.

${ }^{(58)}$ Christiansen, Coinage in Roman Egypt, p. 142. 


\section{Bibliography:}

- Abbas, S., "Some Overstruck Cois From The Time of Heraclius", L'exception ëgyptienne?, Etudes älexandrines 10, (Le Caire, 2005) , p. 339350 .

- AmandryM., \& Planet, F.,"Corpus des Monnaies de coptos", Topoi supplement 3, (Lyon, 2002), pp. 166-171.

- Amer,H., "Le Cute d'osiris an Ier Uiuenaire av. J-C., decouvertes et travaux recents, Actes de la table ronde international tenuea lyon, Maison de l'orient et de la -mediterranee (aniversite lwniere - lyonz) us \& ety Tuimet ,. Bibliotheque d' etude 152, (Le Caire,2010 ), pp. 269-282.

- Bagnall,R., Currency and Inflation in Fourth Century Egypt, (Colombia, 1985).

- Bland,R., "The Roman Coinage of Alexandria, 30 B.C, Archaeological Research in Roman Egypt, The Proceedings of the Seventeenth Classical Colloquium of the Department of Greek and roman Antiquities, British museum, 1 - 4 December 1993, (ed) D. Bailey, (Ann Arbor, 1996) , pp. $113-127$.

- Brunner,T., "A small Hoard of Fourth century Bronze Coins From Egypt", ZPE. 66, (Boon, 1986),p. 285.

- Burnett, A "The Imperial Coinage of Egypt in the Frist century A D., L'exception ëgyptienne?, Ëtudes älexandrines 10, (le cair - 2005) , p. 275290.

- Carson R.,\& Kent,J., Late Roman Bronze coinage A D 324-498, (London, 1960).

- Castrizio,D., le monete della Necropoli Nord de Antinoupolis, (1937 2007), (Firenze, 2010).

- Christiansen, E., Coins of Alexandria, 2 Vols. (Aarhus, 1988).

- Christiansen,E Coins of Alexandria and the Nomes, A supplement to the British museum catalogue, (London, 1991).

- Christiansen,E., Coinage in Roman Egypt, The hoard Evidence, (Aarhus, 2004).

- Christiansen,E., Coins of Alexandria, Proceedings of the $20^{\text {th }}$ International Congress of Papyrologists, Copenhagen 23 - 29, August 1990, (ed) A. B. Jacobson, (Copenhagen, 1994), pp. $478-483$.

- El-Amouri, M., et Picard, O., "Etudes ëxperimentales et Mëtallurgiques du moulage de monnaies et bronze de la fin de l' Empire romain, L'exception ëgyptienne?, Ëtudes älexandrines 10, (Le Carie, 2005), pp. 225 $-252$.

- Emmett,K., Alexandrian Coins, (Wisconsin, 2001). 
- Feuardent,F., Numismatique Egypte ancienne II, domination romaine, (Paris, 1970).

- Geissen,A., "La politique Monëtaire des Antonins", L'exception ëgyptienne?, production et ëchanges monëtaires en Egypte Hellënetique et romaine, Actes du colloque d' Alexandire, 13-15 avril 2002, Ëtudes äLexandrines 10, (le Cairo, 2005), pp. 320-323.

- Hantvedt,R., \& Petrson,E., Coins From karanis, The University of Michigan Excavations, 1924 - 1935, (Ann arbor, 1964).

- Harl,K., Coinage in the Roman Economy, 300 B. c. to a. d. 700, (London, 1996).

- Highly Important Ancient Coins, (London, 1984).

- Howgego,CH., Ancient History From Coins, (London and New York, 2005) .

- Jones,J., A Dictionary of Ancient Roman Coins, (London, 1990) , pp. 319 $-320$.

- Klose,D., \& Ovecbeck,B., Agypten Zur Römerzeit, Antikesleben auf grand der numismatischen Quellen miteinem ägyptologishen Beitrag von Sylvia Schoske, (München, 1989).

- Konig,I., Alexandrinische Munzen, (Trier, 1988).

- Mattingly,H., Coins of the Roman Empire in the British Museum, vol. 5, (London, 1975).

- Milne, J.,Catalogue of the Alexandrian Coins, (Oxford, 1933).

- Milne,J., A History of Egypt under Roman Ruler, ( London, 1924).

- Padro,J., "Excavations in Oxyrhnchus", 120 years of Spanish Archaeology in Egypte, (Cairo, 2009).

- Padro,J., Amer,H., \& Erroux -Morfinm,M., "Decouverte et premiers travaux a' l'osireiond' Oxyrhnchus", IX congres international des egyptologus Grenoble 6-12 deseptembre 2004, OLA 50, (leuven, 2007), pp. 1443-1454.

- Poole,R., Catalogue of the Coins of Alexandria and the Nomes, (Bologna, 1964).

- Sear, D., Byzantine Coins and their values, (London, 1974).

- Sear,D., Greek Imperial coins and their values the Local coinages of the Roman Empire, (London, 1982).

- Sear,D., Greek Imperial Coins and their values, Vol. II, Asia and North Africa, (London, 1951).

- Turner,E., "Roman Oxyrhnchus", JEA 38, (London, 1952), pp. 78-93.

- Uaclennan,H., Oxyrhnchus, An Economic and Social Study, (Amsterdam, 1968) . Bagnall \& D. Rathbone, Egypt From Alexander to the copts, An Archaeological and, Historical Guide, (London, 2004) , p.62. 

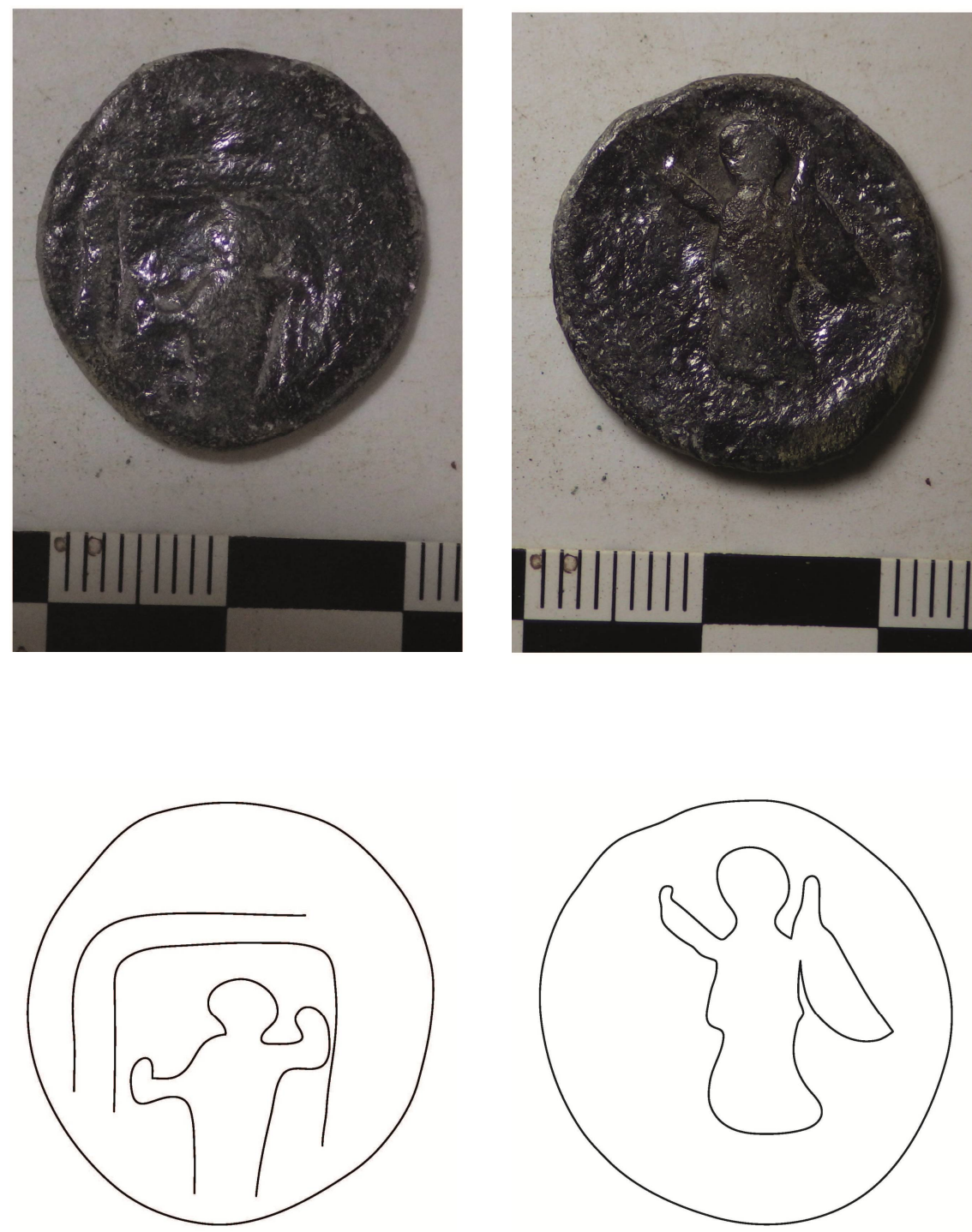

Plate 1

N. 1173 (Photo by Author) 

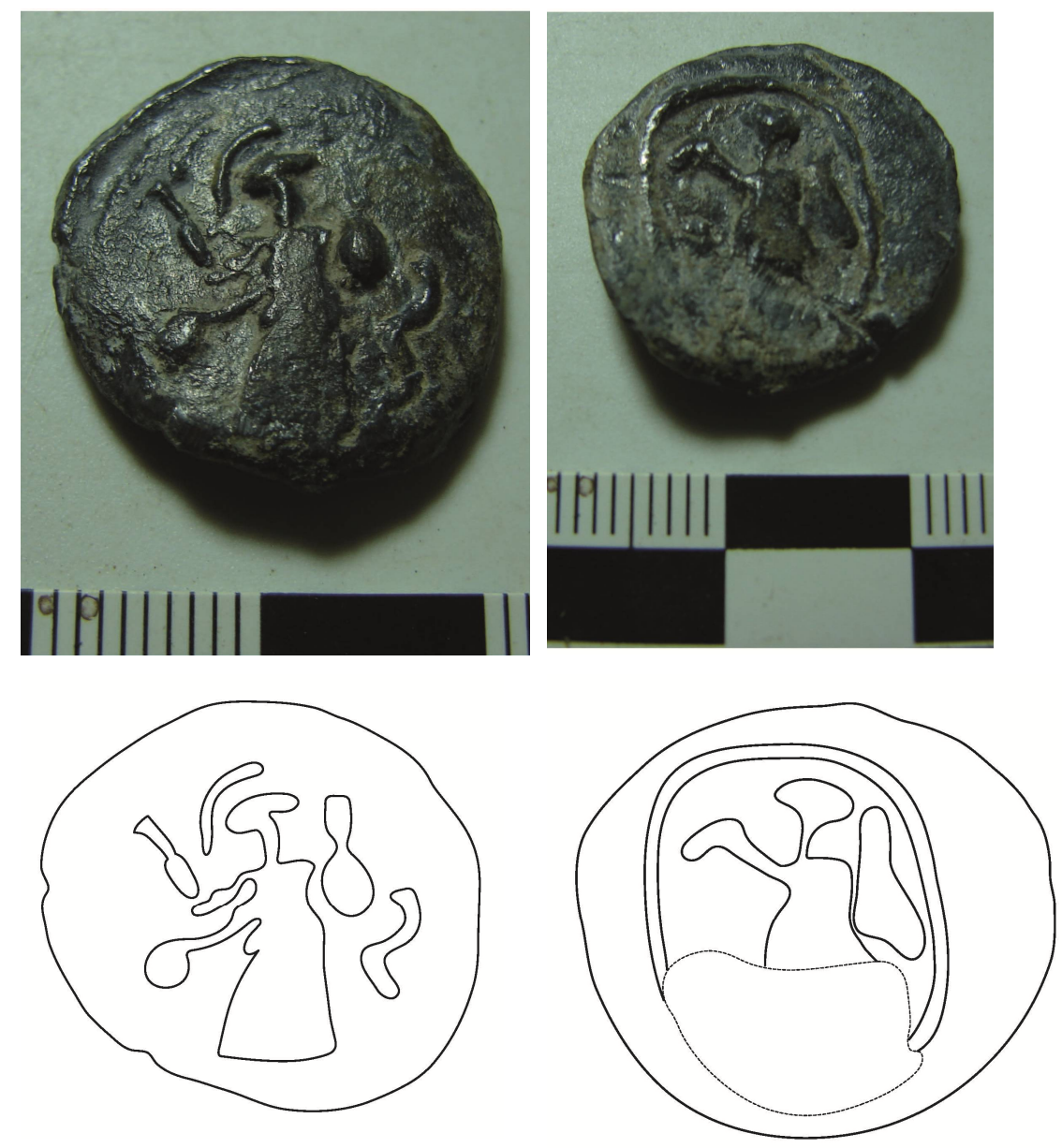

Plate 2

N.1174 (Photo by Author) 

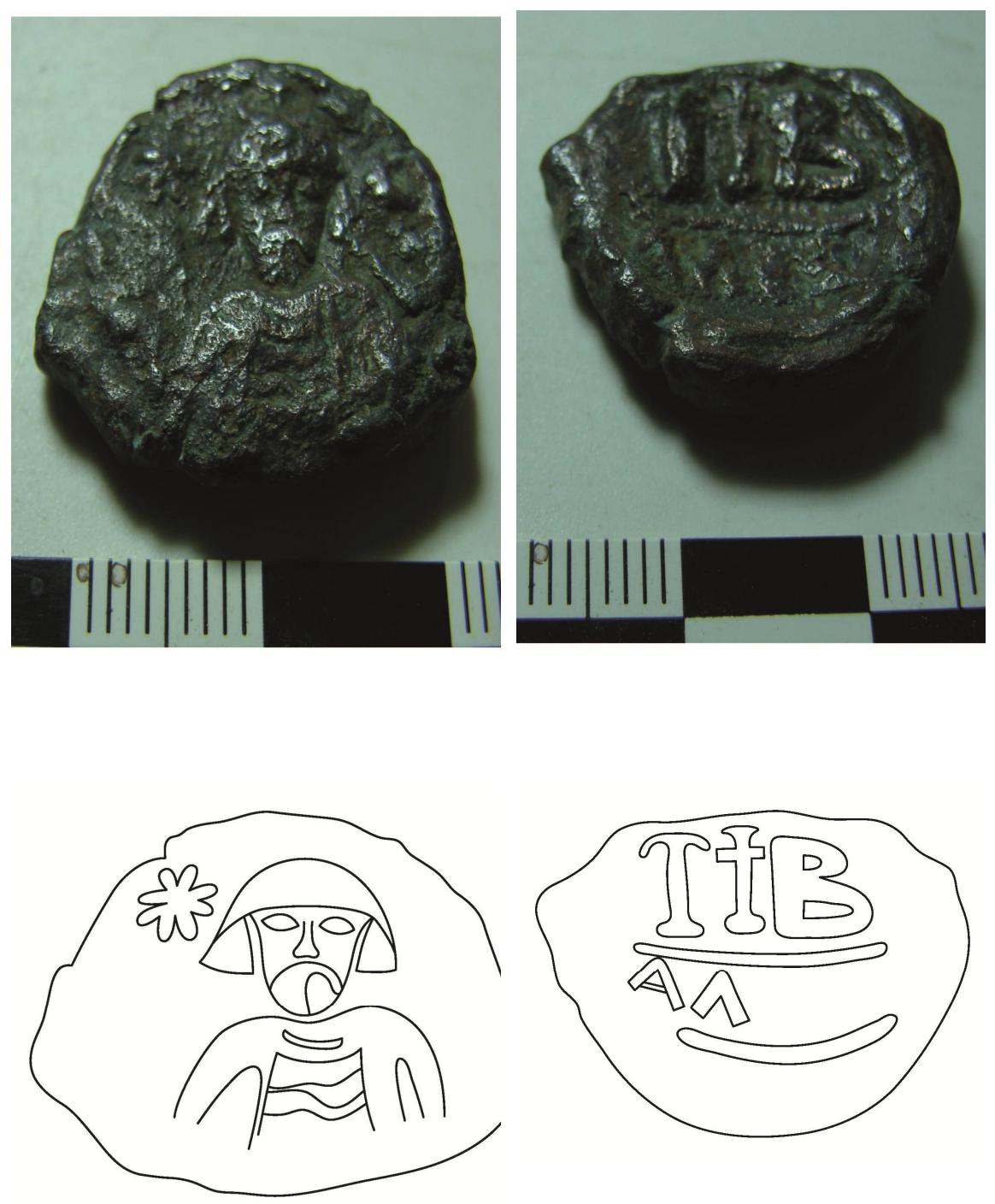

Plate 3

N.1175 (Photo by Author) 


\section{ثلاث عملات رومانية وبيزنطية غير منشورة من أوكسيرينخوس}

منى جبر عبد النبى*

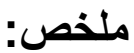

تتناول هذه الورقة البحثية نشر ودراسة لثلاثة قطع من العملات الرومانية

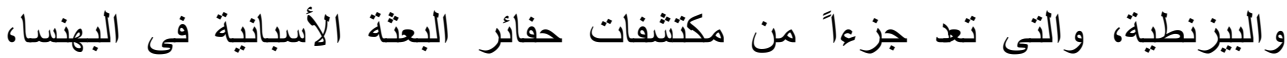

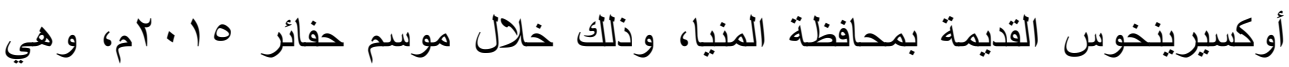

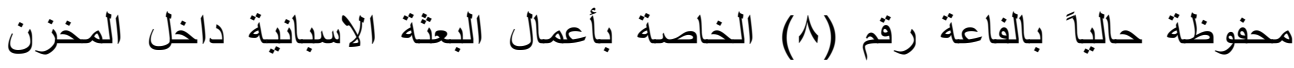
المتحفى بمدينة البهنسا. و هذه القطع هى ذات الأرقام: N.1173, N.1174 والتى تم اكتشافهما فى موقع

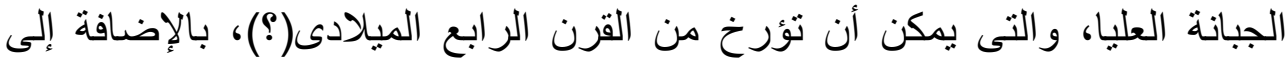

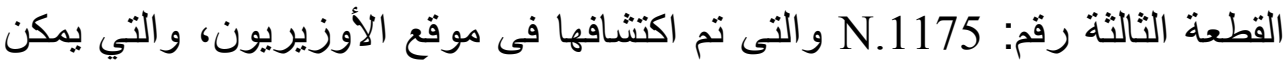

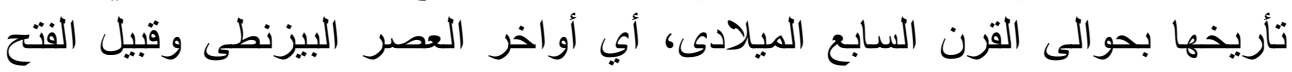

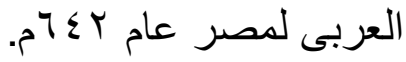

هذه العملات تلقى الضوء وتعطى قراءة تحليلية عن بعض طرز ودور سك

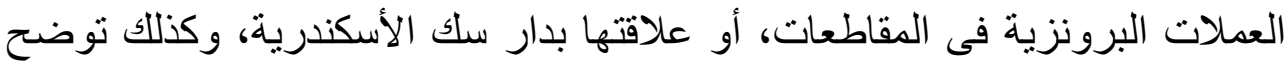
بعض جوانب وضع مصر ودور ها الاقتصادى، لاسيما فيما يتعلق بنظام تداول العملات داخل الإمبر اطورية الرومانية كإحدى الو لايات الرومانية الهامة.

الكلمات الدالة : n البعثة الأسبانية، أوكسيرينخوس، العملات البرونزية، دلالات العملة، دار سك الإسكندرية.

* قسم الآثار اليونانية والرومانية ، كلية الآثار جامعة القاهرة. mona.gabr@hotmail.com ق 